Rohman, et al/Jurnal Ekonomi Syariah Teori dan Terapan Vol. 6 No. 10 Oktober 2019: 2077-2094; PENGARUH SUKU BUNGA, NILAI TUKAR, DPK, DAN NPF/NPL KPR TERHADAP PENYALURAN KPR PERBANKAN DI INDONESIA

\title{
PENGARUH SUKU BUNGA, NILAI TUKAR, DPK, DAN NPF/NPL KPR TERHADAP PENYALURAN KPR PERBANKAN DI INDONESIA ${ }^{1}$
}

\author{
Muchammad Atho'ur Rohman \\ Departemen Ekonomi Syariah-Fakultas Ekonomi dan Bisnis-Universitas Airlangga \\ Email: armanrohman03@gmail.com \\ Siti Zulaikha \\ Departemen Ekonomi Syariah-Fakultas Ekonomi dan Bisnis-Universitas Airlangga \\ Email: iyun.zulaikha@gmail.com
}

\begin{abstract}
:
This study aims to determine the effect of interest rates, exchange rates, third party funds and NPF / NPL Mortgages on the distribution of banking mortgages in Indonesia. It is intended that Islamic banks are able to make optimal policies in the distribution of mortgages and mitigation so that the Islamic banking market share can develop. The data required is secondary data from the Indonesian Banking Statistics report, Islamic Banking Statistics, and Indonesian Economic and Financial Statistics for the period October 2014 May 2019. Based on Multiple Linear Regression, it is known that the simultaneous test results of all variables together have a positive significant effect in the distribution of banking mortgages, and in the partial test it is known that the interest rates and third party funds have a significant positive effect on mortgages in sharia and conventional banking. The exchange rate has a significant positive effect on Islamic banking mortgages, and a significant negative effect on conventional banking mortgages. NPF / NPL mortgage has an insignificant positive effect on the mortgages of both banks. So it can be concluded that the variable interest rates, exchange rates, and third party funds affect the distribution of Islamic banking mortgages and conventional banking mortgages, while the variable NPF / NPL mortgages have no effect.
\end{abstract}

Keywords: Interest rates, exchange rates, third party fund, non performing finance, non performing loan.

\section{PENDAHULUAN}

Bank merupakan lembaga keuangan yang menghimpun dana dari masyarakat dan menyalurkan kembali dana tersebut ke masyarakat serta memberikan jasa layanan bank sebagai kegiatan utamanya. Menjadi penting bagi pihak yang kekurangan dana atau modal usaha dalam menjadikan bank sebagai alternatif ketersediaan modal dalam upaya untuk memenuhi kebutuhan pokoknya ataupun mengembangkan usaha bisnis yang dijalankan. ). Dari segi atau caranya dalam menentukan harga, bank dikelompokan menjadi dua jenis yaitu bank syariah dan bank konvensional (Kasmir, 2012). Perkembangan ekonomi di suatu negara sangat bergantung pada perkembangan dan peran lembaga kevangan seperti perbankan. Perbankan sebagai lembaga keuangan yang memiliki peran penting untuk mengatur, menghimpun, dan menyalurkan dana dibutuhkan untuk membiayai kegiatankegiatan perkonomian yang ada. Salah satu caranya adalah dengan menyalurkan dana dalam bentuk pembiayaan untuk membantu

\footnotetext{
${ }^{1}$ Jurnal ini merupakan bagian dari skripsi dari Muchammad Atho'ur Rohman, NIM: 041511433027, yang diuji pada tanggal 13 Januari 2020.
} 
Rohman, et al/Jurnal Ekonomi Syariah Teori dan Terapan Vol. 6 No. 10 Oktober 2019: 2077-2094; PENGARUH SUKU BUNGA, NILAI TUKAR, DPK, DAN NPF/NPL KPR TERHADAP PENYALURAN KPR PERBANKAN DI INDONESIA

masyarakat yang membutuhkan dana. Sebagai lembaga intermediasi, bank akan berupaya memaksimalkan penyaluran pembiayaan karena selain mensejahterakan masyarakat, bank juga akan mendapatkan laba yang merupakan sumber utama pendapatannya (Nugraheni, 2013).

Salah satu pembiayaan perbankan yang menunjukan pertumbuhan cukup signifikan adalah Kredit Pemilikan Rumah atau KPR. KPR merupakan salah satu jenis pelayanan pembiayaan yang diberikan oleh bank kepada para nasabah yang menginginkan pinjaman khusus untuk memenuhi kebutuhan dalam pembangunan rumah atau renovasi rumah. KPR juga merupakan salah satu pembiayaan yang menjadi kebutuhan masyarakat Indonesia, Karena KPR memudahkan masyarakat dalam memiliki rumah tempat tinggal, sehingga permintaan KPR dari tahun ke tahun terus meningkat seiring meningkatnya angka pertumbuhan penduduk (Hardjono, 2008). Hal ini dibuktikan dengan fakta bahwa permintaan rumah tinggal di Indonesia mencapai 11,4 juta unit dengan rata-rata pertumbuhan kebutuhan baru 800.000 unit per tahunnya, sedangkan pemerintah hanya dapat merealisasikan 1,13 juta unit bantuan KPR subsidi melalui program satu juta rumah di tahun 2018 (PUPR, 2018). Tingginya permintaan serta terbatasnya penawaran tersebut mengindikasikan bahwa pertumbuhan pembiayaan KPR masih akan terus meningkat untuk kedepannya.

Pada perbankan syariah, KPR merupakan pembiayaan tertinggi dibandingkan pembiayaan lainnya, sedangkan untuk perbankan konvensional, KPR merupakan pembiayaan tertinggi ke empat. Berikut merupakan daftar KPR perbankan periode 2014 - Mei 2019 :

Tabel 1.

\section{Pertumbuhan KPR Perbankan beserta}

Komposisinya terhadap pembiayaan

Periode Oktober 2014 - Mei 2019

\begin{tabular}{|c|c|c|c|c|}
\hline Tahun & \multicolumn{2}{|c|}{ Bank Syariah } & \multicolumn{2}{c|}{$\begin{array}{c}\text { Bank } \\
\text { Konvensional }\end{array}$} \\
\hline 2014 & 42.339 & $21.24 \%$ & 299.782 & $8.63 \%$ \\
\hline 2015 & 47.094 & $22.11 \%$ & 318.828 & $8.29 \%$ \\
\hline 2016 & 55.807 & $22.50 \%$ & 338.184 & $8.19 \%$ \\
\hline 2017 & 65.760 & $23.02 \%$ & 369.710 & $8.30 \%$ \\
\hline 2018 & 77.830 & $24.31 \%$ & 412.826 & $8.30 \%$ \\
\hline $2019 *$ & 82.375 & $24.98 \%$ & 428.883 & $8.43 \%$ \\
\hline
\end{tabular}

Sumber: Otoritas Jasa Keuangan, 2019

*Mei 2019

Tabel 1 mengindikasikan bahwa pertumbuhan KPR perbankan syariah dan perbankan konvensional menunjukan tren yang positif dan kemungkinan akan menunjukan pertumbuhan yang stabil di tahun mendatang. Meningkatnya laju pertumbuhan KPR perbankan di Indonesia tentu harus diimbangi dari sisi penawarannya. Untuk dapat menyalurkan KPR, bank memerlukan dana yang akan digunakan untuk membiayai aktivitas tersebut. Dana Pihak Ketiga (DPK) 
Rohman, et al/Jurnal Ekonomi Syariah Teori dan Terapan Vol. 6 No. 10 Oktober 2019: 2077-2094; PENGARUH SUKU BUNGA, NILAI TUKAR, DPK, DAN NPF/NPL KPR TERHADAP PENYALURAN KPR PERBANKAN DI INDONESIA

adalah salah satu sumber dana perbankan yang berasal dari masyarakat dan merupakan sumber dana terbesar yang paling diandalkan perbankan dalam menyalurkan pembiayaan khususnya KPR. DPK diperoleh dari proses penghimpunan dana (funding), melalui instrumen seperti tabungan, deposito, dan giro (Dendawijaya, 2005). Selain itu, dalam mengukur resiko kegagalan pengembalian pembiayaan oleh debitur, bank menggunakan rasio Non Performing Financing/Loan (NPF/NPL). Sesuai dengan peraturan Bank Indonesia dalam No.6/10/PBI/2004, bank diharuskan menjaga besaran NPF/NPL nya pada kisaran 5\%. Sehingga mau tak mau bank harus menjaga kualitas pembiayaannya agar penyaluran KPR tetap meningkat.

Selain faktor internal perbankan, terdapat faktor eksternal yang mampu mempengaruhi penyaluran KPR perbankan, salah satunya adalah suku bunga acuan atau BI 7-Day Repo Rate. Suku bunga merupakan suku bunga kebijakan yang menggambarkan langkah kebijakan moneter yang diterapkan oleh Bl yang diumumkan kepada publik (Putra dan Rustariyuni, 2015). Meningkatnya suku bunga akan mengakibatkan suku bunga tabungan dan deposito akan meningkat dan diikuti oleh meningkatnya suku bunga kredit. Meningkatnya suku bunga kredit dapat menurunkan minat masyarakat untuk mengajukan kredit, sehingga hal tersebut berdampak pada penurunan penyaluran pembiayaan yang dilakukan oleh perbankan.

Selain suku bunga, terdapat nilai tukar yang mampu mempengaruhi penyaluran KPR perbankan. Menurut Mankiw (2000) nilai tukar adalah harga dimana penduduk kedua negara saling melakukan perdagangan. Pergerakan nilai tukar akan berpengaruh pada pembiayaan yang disalurkan karena terdepresiasinya nilai tukar akan diikuti oleh peningkatan biaya produksi khususnya produsen yang menggunakan bahan baku impor sehingga dapat menekan penyaluran kredit perbankan (Kuncoro dan Suhardjono, 2011).

Terdapat hasil penelitian yang berbeda pada beberapa penelitian terdahulu. Pada penelitian Djati (2017) menyatakan bahwa NPL dan suku bunga acuan tidak berpengaruh signifikan terhadap penyaluran KPR. Sedangkan pada penelitian Yusof dkk (2018) dan Adzimatinur dkk (2017) menyatakan bahwa NPF/NPL dan suku bunga acuan berpengaruh signifikan terhadap penyaluran KPR perbankan. Pada penelitian Olokoyo (2011) dan Magud dkk (2014) menyatakan bahwa nilai tukar berpengaruh negatif signifikan terhadap penyaluran pembiayaan dan DPK berpengaruh positif, sedangkan pada Annisa dan Fernanda (2017) dan Sabar dan Kuslin (2018) menyatakan bahwa nilai tukar beperngaruh positif signifikan terhadap penyaluran KPR sedangkan DPK tidak berpengaruh signifikan. 
Rohman, et al/Jurnal Ekonomi Syariah Teori dan Terapan Vol. 6 No. 10 Oktober 2019: 2077-2094; PENGARUH SUKU BUNGA, NILAI TUKAR, DPK, DAN NPF/NPL KPR TERHADAP PENYALURAN KPR PERBANKAN DI INDONESIA

Penelitian ini menjadi penting untuk diteliti karena KPR merupakan pembiayaan tertinggi dalam perbankan syariah dan berdasarkan penelitian terdahulu dapat diketahui bahwa suku bunga, nilai tukar, DPK, NPF/NPL merupakan faktor yang memberikan pengaruh signifikan terhadap pembiayaan walaupun terdapat beberapa penelitian yang berbeda. Maka dari itu penting untuk mengetahui dan menganalisis pengaruh suku bunga, nilai tukar, DPK, NPF/NPL KPR terhadap penyaluran KPR perbankan syariah dan perbankan konvensional di Indonesia.

\section{LANDASAN \\ TEORI \\ DAN}

PENGEMBANGAN HIPOTESIS

\section{Penyaluran Kredit}

Menurut Undang-Undang pasal 1 ayat 11 UU No.10 tahun 1998 tentang perbankan, pembiayaan atau kredit adalah penyediaan vang atau tagihan yang dapat disamakan dengan itu, berdasarkan persetujuan atau kesepakatan pinjam-meminjam antara bank dengan pihak lain yang mewajibkan pihak peminjam untuk melunasi utangnya setelah jangka waktu tertentu dengan pemberian bunga. Dalam penyalurannya bank pada umumnya melakukan kegiatan pembiayaan mencapai $70 \%$ $80 \%$ dari seluruh kegiatan usaha perbankan, dimana dana - dana yang dapat dihimpun oleh masyarakat mencapai $80 \%$ - $90 \%$ dari seluruh dana perbankan (Dendawijaya, 2005). Adapun prinsip -prinsip yang digunakan oleh perbankan dalam menentukan debitur adalah dengan menggunakan instrumen analisa asas 5C, diantaranya adalah character, capacity, capital, condition of economic, collateral (Hasibuan, 2008). Sedangkan konsep penyaluran kredit menurut pandangan syariah adalah penyediaan uang atau tagihan yang dipersamakan dengan itu berdasarkan persetujuan atau kesepakatan antara bank dengan pihak lain yang mewajibkan pihak yang dibiayai untuk mengembalikan vang atau tagihan tersebut setelah jangka waktu tertentu dengan imbalan atau bagi hasil. Berdasarkan surat al-Maidah ayat 2, tujuan diberikannya pembiayaan tidak lain adalah untuk adalah untuk menghilangkan kesusahan, memberi bantuan bagi yang membutuhkan dan menguatkan rasa cinta kasih di antara sesama manusia, karena Orang yang menghilangkan kesusahan dari orang yang membutuhkan akan menjadi orang yang dekat dengan rahmat Allah (Fikri, 1357). Adapun jenis pembiayaan perbankan syariah menurut $\mathrm{PBI}$ No.7/46/PBI/2005 Pasal 18 diantaranya adalah Murabahah, Ijarah, Istishna, Mudharabah, Musyarakah.

\section{Pengaruh Suku Bunga Terhadap KPR}

Menurut Bank Indonesia, tingkat bunga atau BI 7-Day Repo Rate adalah suku bunga kebijakan yang mencerminkan sikap atau stance kebijakan moneter yang ditetapkan oleh Bank Indonesia dan diumumkan kepada 
Rohman, et al/Jurnal Ekonomi Syariah Teori dan Terapan Vol. 6 No. 10 Oktober 2019: 2077-2094; PENGARUH SUKU BUNGA, NILAI TUKAR, DPK, DAN NPF/NPL KPR TERHADAP PENYALURAN KPR PERBANKAN DI INDONESIA

publik. Meningkatnya suku bunga akan mengakibatkan suku bunga tabungan dan deposito akan meningkat dan diikuti oleh meningkatnya suku bunga kredit. Meningkatnya suku bunga kredit dapat menurunkan minat masyarakat untuk mengajukan kredit, sehingga hal tersebut berdampak pada penurunan penyaluran pembiayaan yang dilakukan oleh perbankan. Pada perbankan syariah, peningkatan suku bunga juga akan diikuti oleh meningkatnya tingkat imbal hasil kepada dana pihak ketiga, dan meningkatnya tingkat margin keuntungan atau bagi hasil kepada nasabah. Sehingga hal tersebut akan berpengaruh negatif pada penyaluran pembiayaan khususnya KPR sesuai dengan penelitian Amaliawati (2013) dan Putra (2014). Namun terdapat penelitian lain yang mengindikasikan bahwa suku bunga berpengaruh positif terhadap pembiayaan yaitu Katmas (2014).

\section{Pengaruh Nilai Tukar Terhadap KPR}

Selain Suku bunga, terdapat nilai tukar sebagai faktor eksternal yang juga turut mempengaruhi jumlah penyaluran pembiayaan perbankan di Indonesia. Menurut Mankiw (2000) nilai tukar adalah harga dimana penduduk kedua negara saling melakukan perdagangan. Pergerakan nilai tukar akan berpengaruh pada pembiayaan yang disalurkan karena terdepresiasinya nilai tukar akan diikuti oleh peningkatan biaya produksi khususnya produsen yang menggunakan bahan baku impor sehingga dapat meningkatkan harga barang domestik yang membuat penyaluran kredit perbankan mengalami penurunan (Kuncoro dan Suhardjono, 2011). Namun terdapat penelitian lain yang menemukan bahwa terdepresiasinya nilai tukar dapat meningkatkan pembiayaan yaitu Sabar dan Kuslin (2018).

\section{Pengaruh DPK Terhadap KPR}

Menurut Rinaldy (2008) Dana pihak ketiga (DPK) merupakan dana yang dipercayakan masyarakat (di luar bank) kepada bank berdasarkan perjanjian penyimpanan dana. Dana - dana yang dihimpun dari masyarakat ini merupakan sumber dana terbesar yang paling diandalkan oleh bank, dimana dapat mencapai $80 \%-90 \%$ dari seluruh dana yang dikelola oleh bank. Secara operasional perbankan, DPK merupakan sumber likuiditas untuk memperlancar pembiayaan yang terdapat pada sisi aktiva neraca bank. Sehingga semakin banyak DPK yang berhasil dihimpun oleh bank, maka akan semakin banyak pula pembiayaan yang dapat disalurkan oleh bank tersebut. Maka dapat disimpulkan bahwa DPK berpengaruh positif pada penyaluran pembiayaan khususnya KPR sesuai dengan penelitian Olokoyo (2011) dan Adzimatinur dkk (2015). Namun terdapat penelitian lain yang mengindikasikan bahwa DPK berpengaruh negatif terhadap pembiayaan yaitu Annisa Fernanda (2017).

\section{Pengaruh NPF/NPL Terhadap KPR}


Rohman, et al/Jurnal Ekonomi Syariah Teori dan Terapan Vol. 6 No. 10 Oktober 2019: 2077-2094; PENGARUH SUKU BUNGA, NILAI TUKAR, DPK, DAN NPF/NPL KPR TERHADAP PENYALURAN KPR PERBANKAN DI INDONESIA

Menurut Siamat (2005) NPL merupakan presentase kredit bermasalah dengan kategori kurang lancar, diragukan, dan macet dibandingkan dengan jumlah kredit yang disalurkan oleh bank. Non performing loan atau NPL merupakan rasio yang mencerminkan risiko kredit. Menurut ketentuan Bl, perbankan diwajibkan untuk menjaga rasio NPF/NPL nya berada di bawah $5 \%$. Tingginya rasio NPF/NPL perbankan akan membuat modal bank akan terkikis karena harus menyediakan pencadangan yang lebih besar, sehingga semakin besar tingkat NPF/NPL nya maka akan semakin menurunkan penyaluran pembiayaan khususnya KPR, karena modal perbankan yang terkikis dan juga hilangnya minat perbankan dalam menyalurkan pembiayaan pada sektor tersebut. Hal tersebut sesuai dengan penelitian Tracey (2008) dan Kusumawati (2013) yang menyatakan bahwa NPF/NPL berpengaruh negatif terhadap pembiayaan. Namun terdapat penelitian lain yang mengindikasikan bahwa NPF/NPL berpengaruh positif terhadap pembiayaan yaitu Pratami (2011) dan Djati (2017)

\section{Model Penelitian}

Berdasarkan uraian yang telah dijelaskan, maka dapat digambarkan model penelitian dalam penelitian ini adalah sebagai berikut:

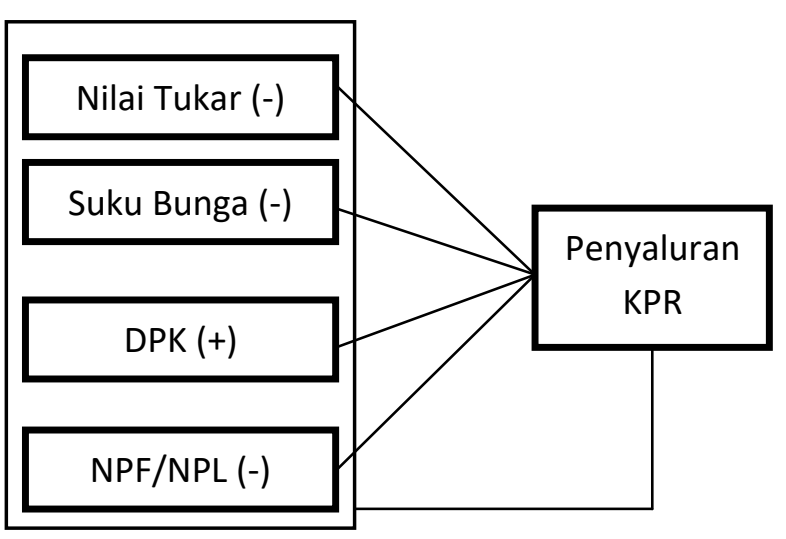

Gambar 1.

Skema gambar kerangka model penelitian.

\section{Perumusan Hipotesis}

Berdasarkan pada latar belakang dan tinjauan penelitian terdahulu yang telah dilakukan, maka hipotesis yang diajukan dalam penelitian ini adalah sebagai berikut :

H1: Terdapat pengaruh negatif signifikan suku bunga terhadap penyaluran KPR Perbankan Syariah dan perbankan konvensional.

H2 : Terdapat pengaruh negatif signifikan nilai tukar terhadap penyaluran KPR Perbankan Syariah dan perbankan konvensional.

H3 : Terdapat pengaruh positif signifikan Dana Pihak Ketiga terhadap penyaluran KPR Perbankan Syariah dan perbankan konvensional.

H4: Terdapat pengaruh negatif signifikan NPF/NPL terhadap penyaluran KPR Perbankan Syariah dan perbankan konvensional.

H5: Terdapat pengaruh positif signifikan suku bunga, nilai tukar, 
Rohman, et al/Jurnal Ekonomi Syariah Teori dan Terapan Vol. 6 No. 10 Oktober 2019: 2077-2094; PENGARUH SUKU BUNGA, NILAI TUKAR, DPK, DAN NPF/NPL KPR TERHADAP PENYALURAN KPR PERBANKAN DI INDONESIA

DPK, NPF/NPL secara simultan terhadap penyaluran KPR Perbankan Syariah dan perbankan konvensional.

\section{METODE PENELITIAN}

\section{Variabel Penelitian dan Definisi Operasional}

KPR (Kredit Pemilikan Rumah) adalah kredit yang digunakan untuk membeli rumah tinggal, apartemen, ruko (rumah toko), rukan (rumah kantor), atau tanah dengan jaminan/agunan berupa rumah (BTN, 2018). Sedangkan penyaluran KPR merupakan jumlah kredit KPR yang disalurkan oleh bank. Variabel penyaluran KPR dalam penelitian ini merupakan variabel dependen. Untuk menghindari distribusi data yang tidak normal maka sampel data akan ditransformasi ke dalam bentuk Lag.

Menurut Bank Indonesia, tingkat bunga atau BI 7-Day Repo Rate adalah suku bunga kebijakan yang mencerminkan sikap atau stance kebijakan moneter yang ditetapkan oleh Bank Indonesia dan diumumkan kepada publik.. Satuan yang digunakan adalah persen (\%).

Kurs/nilai tukar/exchange rate diantara dua negara adalah harga dimana penduduk kedua negara saling melakukan perdagangan (Mankiw, 2000). . Dalam penelitian ini kurs yang digunakan adalah kurs tengah rupiah/dolar AS dalam jangka waktu bulanan. Satuan nilai tukar berupa dalam jumlah mata uang rupiah yang diukur dengan rumus Lag. Kurs tengah ini dirumuskan sebagai berikut :

Kurs Tengah $\mathrm{BI}=\frac{\text { Nilai } \text { Kurs Jual+Nilai Kurs Beli }}{2}$

Menurut Rinaldy (2008) Dana pihak ketiga (DPK) merupakan dana yang dipercayakan masyarakat (di luar bank) kepada bank berdasarkan perjanjian penyimpanan dana. Satuan DPK berupa dalam jumlah mata vang rupiah yang diukur dengan rumus Lag.

Menurut Siamat (2005) NPF/NPL merupakan presentase kredit bermasalah dengan kategori kurang lancar, diragukan, dan macet dibandingkan dengan jumlah kredit yang disalurkan oleh bank. Rasio ini dirumuskan sebagai berikut:

$$
\text { NPL }=\frac{\text { Total Kredit Bermasalah }}{\text { Total Kredit Yang Disalurkan }} \times 100 \%
$$

\section{Populasi dan Sampel}

Populasi dalam penellitian ini adalah seluruh perbankan syariah dan perbankan konvensional yang terdaftar di Otoritas Jasa Kevangan pada bulan Oktober 2014 - Mei 2019. Penentuan sampel dalam penelitian ini menggunakan metode purposive sampling dengan kriteria bank syariah yang terdiri dari bank umum syariah dan unit usaha syariah serta bank umum konvensional yang tidak termasuk unit usaha syariah; bank syariah dan bank umum konvensional menerbitkan dan melaporkan laporan keuangan pada OJK secara berturut - turut.

\section{Jenis dan Sumber Data}

Jenis data yang digunakan dalam penelitian ini adalah data sekunder atau berupa data kuantitatif dengan sumber 
Rohman, et al/Jurnal Ekonomi Syariah Teori dan Terapan Vol. 6 No. 10 Oktober 2019: 2077-2094; PENGARUH SUKU BUNGA, NILAI TUKAR, DPK, DAN NPF/NPL KPR TERHADAP PENYALURAN KPR PERBANKAN DI INDONESIA

data dari laporan Statistik Perbankan Indonesia dan Statistik Perbankan Syariah dari OJK, serta Statistik Ekonomi dan Keuangan Indonesia dari BI.

\section{Teknik Pengumpulan Data}

Metode pengumpulan data penelitian ini adalah data sekunder. Data sekunder diperoleh dari data yang berbentuk laporan keuangan yang dipublikasikan di website OJK, dan Bank Indonesia. Data yang digunakan dalam penelitian ini adalah data sekunder yang bersifat data urutan waktu (timeseries).

\section{Metode Analisis Data}

Pengujian hipotesis dalam penelitian ini menggunakan model regresi linier berganda untuk memperoleh gambaran yang menyeluruh mengenai pengaruh antara suku bunga, nilai tukar, DPK, NPF/NPL terhadap penyaluran KPR perbankan syariah dan perbankan konvensional, dengan model persamaan sebagai berikut:

$Y_{1}=a+b_{1} X_{1}+b_{2} X_{2}+b_{3} X_{3}+b_{5} X_{5}+e$

$Y_{2}=a+b_{1} X_{1}+b_{2} X_{2}+b_{4} X_{4}+b_{6} X_{6}+e$

$Y_{1}$ : Penyaluran KPR perbankan syariah

$Y_{2}$ : Penyaluran KPR perbankan konvensional

a: Kontanta

$\mathrm{X}_{1}$ : $\quad$ Suku Bunga Acuan

$\mathrm{X}_{2}$ : $\quad$ Nilai Tukar

$\mathrm{X}_{3}$ : $\quad$ DPK perbankan syariah

$\mathrm{X}_{4}$ : $\quad$ DPK perbankan konvensional

$X_{5}: \quad N P F$

$X_{6}: \quad N P L$

e : Kesalahan

IV. HASIL DAN PEMBAHASAN

\section{Statistik Deskriptif}

Gambaran secara umum semua variabel yang digunakan dalam analisis regresi disajikan dalam statitik deskriptif pada tabel berikut:

Tabel 2.

Analisis Deskriptif

\begin{tabular}{|c|c|c|c|c|c|}
\hline & $\mathrm{N}$ & $\begin{array}{l}\text { Minim } \\
\text { um }\end{array}$ & $\begin{array}{l}\text { Maxim } \\
\text { um }\end{array}$ & Mean & $\begin{array}{c}\text { Std. } \\
\text { Deviatio } \\
\mathrm{n}\end{array}$ \\
\hline KPRS & 56 & 41194 & 82375 & 58290.80 & 12436.98 \\
\hline \multirow[b]{2}{*}{ KPRK } & \multirow[b]{2}{*}{56} & 29535 & \multirow[b]{2}{*}{428883} & 348005.3 & 38789.21 \\
\hline & & 8 & & 6 & 0 \\
\hline SB & 56 & 4.25 & 7.75 & 5.9152 & 1.26156 \\
\hline \multirow{2}{*}{ ER } & \multirow{2}{*}{56} & 12082 & 15227. & 13591.62 & 632.7988 \\
\hline & & .00 & 00 & 50 & 2 \\
\hline \multirow{2}{*}{ DPKS } & \multirow{2}{*}{56} & 20712 & 382734 & 283656.7 & 58472.12 \\
\hline & & & & 5 & \\
\hline \multirow{2}{*}{ DPKK } & \multirow{2}{*}{56} & 38042 & 529567 & 4574683. & 454273.1 \\
\hline & & 47 & 0 & 27 & 27 \\
\hline NPF & 56 & 2.04 & 3.60 & 2.6049 & .30378 \\
\hline NPL & 56 & 2.06 & 3.06 & 2.7517 & .23238 \\
\hline Valid & 56 & & & & \\
\hline $\mathrm{N}$ & 56 & & & & \\
\hline
\end{tabular}

Analisis Data

Analisis data dalam penelitian ini menggunakan uji asumsi klasik (Uji multikolineritas, uji heterokedatisitas, uji autokrelasi, uji normalitas), Analisis uji regresi linier berganda, dan uji hipotesis.

Uji Multikolineritas

Model dinyatakan bebas dari gangguan multikolinearitas jika mempunyai nilai VIF dibawah 10 atau tolerance diatas 0,1 (Ghozali, 2011). Adapun hasil uji multikolinearitas pada perbankan syariah dan perbank konvensional sebagai berikut: 
Rohman, et al/Jurnal Ekonomi Syariah Teori dan Terapan Vol. 6 No. 10 Oktober 2019: 2077-2094; PENGARUH SUKU BUNGA, NILAI TUKAR, DPK, DAN NPF/NPL KPR TERHADAP PENYALURAN KPR PERBANKAN DI INDONESIA

Tabel 3.

\section{Uji Multikolineritas}

\begin{tabular}{|l|r|r|r|r|}
\hline \multirow{2}{*}{$\begin{array}{l}\text { Perbanka } \\
\text { n Syariah }\end{array}$} & \multicolumn{2}{|c|}{$\begin{array}{c}\text { Unstandardized } \\
\text { Coefficients }\end{array}$} & \multicolumn{2}{|c|}{$\begin{array}{c}\text { Collinearity } \\
\text { Statistics }\end{array}$} \\
\cline { 2 - 5 } & \multicolumn{1}{c|}{$\mathrm{B}$} & Std. Error & $\begin{array}{c}\text { Toleran } \\
\text { ce }\end{array}$ & \multicolumn{1}{c|}{ VIF } \\
\hline (Constan & -3.086 & .491 & & \\
Lag_SB & .081 & .025 & .477 & $\begin{array}{r}2.09 \\
8\end{array}$ \\
Lag_ER & .321 & .104 & .575 & $\begin{array}{r}1.73 \\
8\end{array}$ \\
Lag_DPK & 1.035 & .035 & .275 & $\begin{array}{r}3.63 \\
8\end{array}$ \\
S & & & & 1.73 \\
Lag_NPF & .043 & .035 & .577 & 5 \\
\hline
\end{tabular}

\begin{tabular}{|c|c|c|c|c|}
\hline \multirow{2}{*}{$\begin{array}{l}\text { Perbankan } \\
\text { Konvensio } \\
\text { nal }\end{array}$} & \multicolumn{2}{|c|}{$\begin{array}{l}\text { Unstandardized } \\
\text { Coefficients }\end{array}$} & \multicolumn{2}{|c|}{$\begin{array}{l}\text { Collinearity } \\
\text { Statistics }\end{array}$} \\
\hline & $B$ & Std. Error & $\begin{array}{c}\text { Toleranc } \\
e\end{array}$ & VIF \\
\hline lConstant & 1.912 & .245 & & \\
\hline Lag_SB2 & .103 & .020 & .582 & $\begin{array}{r}1.71 \\
9\end{array}$ \\
\hline Lag_ER2 & -.178 & .068 & .664 & $\begin{array}{r}1.50 \\
7\end{array}$ \\
\hline $\begin{array}{l}\text { Lag_DPKK } \\
2\end{array}$ & 1.278 & .051 & .484 & $\begin{array}{r}2.06 \\
8\end{array}$ \\
\hline Lag_NPL2 & .014 & .025 & .885 & $\begin{array}{r}1.13 \\
0\end{array}$ \\
\hline
\end{tabular}

Tabel 3 menunjukan bahwa semua

variabel baik dari perbankan syariah ataupun perbankan konvensional memiliki nilai tolerance lebih dari 0,1 dan nilai VIF dibawah 10. Jadi dapat disimpulkan bahwa tidak ada multikolinearitas antar variabel indepnden dalam model regresi.

\section{Uji Heterekedastisitas}

Uji ini menggunakan alat uji scatterplot guna mendeteksi ada tidaknya hubungan antar variabel terikat dengan variabel bebas. Dalam Scatterplot jika titik menyebar dan tidak membentuk pola yang khas maka uji regresi tidak terkena heterokedastisitas. Hasil Uji heterokedastisitas dalam penelitian ini sebagai berikut:
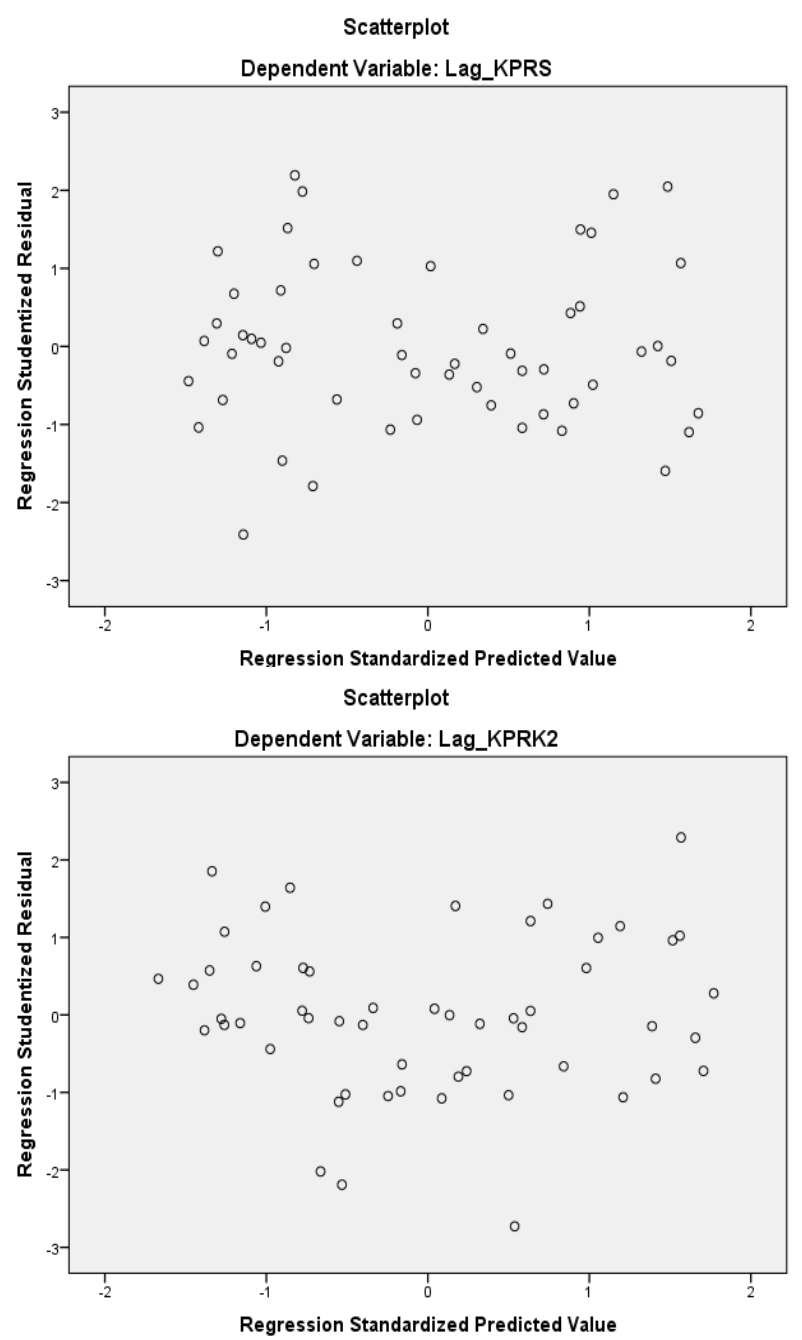

Gambar 2.

\section{Hasil Uji Heterokedastisitas Perbankan}

\section{Syariah dan Konvensional}

Gambar 2 menunjukan bahwa tidak ada pola tertentu, serta titik-titik yang menyebar tidak menunjukan pola tertentu pada sumbu Y. sehingga dapat disimpulkan bahwa model regresi dalam penelitian ini tidak mengandung adanya heterokedastisitas.

\section{Uji Autokrelasi}


Rohman, et al/Jurnal Ekonomi Syariah Teori dan Terapan Vol. 6 No. 10 Oktober 2019: 2077-2094; PENGARUH SUKU BUNGA, NILAI TUKAR, DPK, DAN NPF/NPL KPR TERHADAP PENYALURAN KPR PERBANKAN DI INDONESIA

Uji Autokrelasi pada penelitian ini dilakukan dengan uji Durbin-Watson guna mendeteksi korelasi yang terjadi antara anggota observasi yang terletak berderetan (Ghozali, 2011). Apabila terdapat masalah dalam autokeralasi dalam data maka penelitian dapat menggunakan metode Cochrane-Orchutt untuk mengatasi permasalahan tersebut (Gujarati 2003). Adapun hasil uji autokrelasi sebagai berikut:

Tabel 4.

Hasil Uji Durbin-Watson Perbankan Syariah

\begin{tabular}{|c|r|r|}
\hline$R$ & R Square & \multicolumn{1}{c|}{$\begin{array}{c}\text { Durbin- } \\
\text { Watson }\end{array}$} \\
\hline $.992 \mathrm{a}$ & .983 & 1.875 \\
\hline
\end{tabular}

Tabel 5.

Hasil Uji Durbin-Watson Perbankan Konvensional

\begin{tabular}{|c|r|r|}
\hline$R$ & $R$ Square & \multicolumn{1}{c|}{$\begin{array}{c}\text { Durbin- } \\
\text { Watson }\end{array}$} \\
\hline $.976 a$ & .952 & 1.776 \\
\hline
\end{tabular}

Berdasarkan pada tabel 4 dan 5 , diketahui bahwa nilai du adalah 1,7246 sehingga nilai durbin-watson baik dari perbankan syariah dan perbankan konvensional lebih besar dari batas atas (du) 1,7246 dan kurang dari 2,2782 (41,7246), maka dapat disimpulkan bahwa tidak terdapat autokorelasi pada perbankan syariah dan perbankan konvensional.

\section{Uji Normalitas}

Uji normalitas pada penelitian ini menggunakan uji kolmogrov-smirnov guna menguji apakah dalam model regresi, variabel pengganggu atau residual memiliki distrbusi normal (Ghozali, 2011). Adapun hasil Uji Normalitas sebagai berikut:

Tabel 6

Uji Normalitas

\begin{tabular}{|l|l|r|}
\hline \multicolumn{2}{|c|}{ Perbankan Syariah } & $\begin{array}{r}\text { Unstandardiz } \\
\text { ed Residual }\end{array}$ \\
\hline $\mathrm{N}$ & 55 \\
\hline $\begin{array}{l}\text { Normal } \\
\text { Parameters } \\
\text { a,b }\end{array}$ & Mean & OE-7 \\
\cline { 2 - 3 } $\begin{array}{l}\text { Most } \\
\text { Extreme } \\
\text { Differences }\end{array}$ & Std. Deviation & .01579337 \\
\cline { 2 - 3 } & Absolute & .099 \\
\hline Kolmogorovitive & Negative & .099 \\
\hline Asymp. Sig. (2-tailed) & .069 \\
\hline
\end{tabular}

\begin{tabular}{|l|l|r|}
\hline \multicolumn{2}{|l|}{ Perbankan Konvensional } & $\begin{array}{r}\text { Unstandardize } \\
\text { d Residual }\end{array}$ \\
\hline $\mathrm{N}$ & 54 \\
\hline $\begin{array}{l}\text { Normal } \\
\text { Parametersa } \\
\text {.b }\end{array}$ & Mean & $0 \mathrm{E}-7$ \\
\cline { 2 - 3 } $\begin{array}{l}\text { Most } \\
\text { Extreme } \\
\text { Differences }\end{array}$ & Std. Deviation & .00864907 \\
\cline { 2 - 3 } & Positive & .094 \\
\hline Kolmogorov-Smirnov Z & .094 \\
\hline Asymp. Sig. (2-tailed) & -.087 \\
\hline
\end{tabular}

Berdasarkan pada tabel 6, dapat diketahui bahwa nilai Asiymp.Sig (2-tailed) untuk perbankan syariah adalah sebesar 0,651 dan untuk perbankan konvensional sebesar 0,731. Hal ini menunjukan dalam penelitian ini nilai Asiymp.Sig (2-tailed) melebihi 0,05 yang artinya adalah data telah terdistribusi dengan normal dan lolos uji normalitas.

\section{Uji Regresi Linier Berganda}


Rohman, et al/Jurnal Ekonomi Syariah Teori dan Terapan Vol. 6 No. 10 Oktober 2019: 2077-2094; PENGARUH SUKU BUNGA, NILAI TUKAR, DPK, DAN NPF/NPL KPR TERHADAP PENYALURAN KPR PERBANKAN DI INDONESIA

Analisis regresi linier berganda merupakan model analisis untuk mengetahui hubungan suku bunga, nilai tukar, DPK, dan NPF/NPL terhadap penyaluran KPR perbankan syariah dan perbankan konvensional. Berikut merupakan hasil uji parsial yang diperoleh dari uji analisis regresi linier berganda :

Tabel 7.

Uji Regresi Linier Berganda

\begin{tabular}{|c|c|c|c|c|}
\hline \multirow{2}{*}{$\begin{array}{l}\text { Perbanka } \\
\text { n Syariah }\end{array}$} & \multicolumn{2}{|c|}{$\begin{array}{c}\text { Unstandardized } \\
\text { Coefficients }\end{array}$} & \multirow[t]{2}{*}{$\dagger$} & \multirow[t]{2}{*}{ Sig. } \\
\hline & $B$ & Std. Error & & \\
\hline $\begin{array}{l}\text { (Constan } \\
\text { †) }\end{array}$ & -3.086 & .491 & -6.290 & .000 \\
\hline Lag_SB & .081 & .025 & 3.212 & .002 \\
\hline Lag_ER & .321 & .104 & 3.094 & .003 \\
\hline Lag_DPKS & 1.035 & .035 & 29.414 & .000 \\
\hline Lag_NPF & .043 & .035 & 1.232 & .224 \\
\hline
\end{tabular}

\begin{tabular}{|l|r|r|r|r|}
\hline $\begin{array}{c}\text { Perbankan } \\
\text { Konvension } \\
\text { al }\end{array}$ & \multicolumn{2}{|c|}{$\begin{array}{c}\text { Unstandardized } \\
\text { Coefficients }\end{array}$} & \multicolumn{1}{c|}{ T } & \multirow{2}{*}{ Sig. } \\
\cline { 2 - 4 } & \multicolumn{1}{c|}{ B } & \multicolumn{1}{|c|}{ Std. Error } & & \\
\hline (Constant) & -1.912 & .245 & -7.791 & .000 \\
\hline Lag_SB2 & .103 & .020 & 5.094 & .000 \\
\hline Lag_ER2 & -.178 & .068 & -2.606 & .012 \\
\hline Lag_DPKK2 & 1.278 & .051 & 24.857 & .000 \\
\hline Lag_NPL2 & .014 & .025 & .553 & .583 \\
\hline
\end{tabular}

Berdasarkan Tabel 7 menunjukan hasil analisis dengan program SPSS sehingga dapat diketahui persamaan regresi yang terbentuk. Adapun persamaan regresi linier yang terbentuk pada penyaluran KPR perbankan syariah adalah sebagai berikut:

$$
\begin{aligned}
& Y_{1}=-3,086+0,081 X 1+0,321 X 2+1,035 \\
& X 3+0,043 X_{5}+e
\end{aligned}
$$

Berdasarkan persamaan tersebut dapat dijelaskan bahwa nilai koefisien dari variabel suku bunga adalah positif signifikan yaitu sebesar 0,081 dengan tingkat probabilitasnya adalah sebesar 0,002 . Artinya pertumbuhan suku bunga berpengaruh terhadap penyaluran KPR perbankan syariah. Sehingga apabila terjadi kenaikan suku bunga sebanyak 1 persen maka akan menyebabkan kenaikan pada penyaluran KPR perbankan syariah sebesar 0,081 persen dengan asumsi variabel lain konstan. Hasil tersebut mengindikasikan bahwa $\mathrm{H}_{1}$ yaitu suku bunga berpengaruh negatif signifikan terhadap KPR ditolak, dan hasil ini didukung oleh hasil penelitian Darmawan (2017) yang menyatakan bahwa perbankan belum sepenuhnya beracuhan pada $\mathrm{Bl}$ Rate dalam menentukan suku bunganya, serta Yusof dkk (2017) yang menyatakan bahwa suku bunga Bank Negara Malaysia berpengaruh signifikan positif pada pembiayaan rumah baik dalam jangka pendek maupun jangka panjang.

Kemudian, pada variabel nilai tukar nilai koefisien regresinya adalah positif yaitu sebesar 0,321 dengan tingkat probabilitasnya adalah sebesar 0,003. Artinya pertumbuhan nilai tukar berpengaruh terhadap penyaluran KPR perbankan syariah. Sehingga apabila terjadi kenaikan nilai tukar sebanyak 1 persen maka akan menyebabkan kenaikan pada penyaluran KPR perbankan syariah sebesar 0,321 persen dengan asumsi variabel lain konstan. Hasil tersebut mengindikasikan bahwa $\mathrm{H}_{2}$ yaitu 
Rohman, et al/Jurnal Ekonomi Syariah Teori dan Terapan Vol. 6 No. 10 Oktober 2019: 2077-2094; PENGARUH SUKU BUNGA, NILAI TUKAR, DPK, DAN NPF/NPL KPR TERHADAP PENYALURAN KPR PERBANKAN DI INDONESIA

nilai tukar berpengaruh negatif signifikan terhadap KPR ditolak, dan didukung oleh hasil penelitian Tandris (2014) yang menyatakan bahwa nilai tukar berpengaruh positif signifikan terhadap permintaan kredit di kota Manado, serta Sabar dan Kuslin (2018) yang menyatakan bahwa nilai tukar berpengaruh positif signifikan terhadap permintaan kredit konsumsi di Sulawesi Selatan.

Pada Variabel internal perbankan yakni DPK menunjukan nilai koefisien regresi yang positif signifikan yaitu sebesar 1,035 dengan tingkat probabilitasnya adalah 0,000 . Artinya pertumbuhan DPK berpengaruh terhadap penyaluran KPR perbankan syariah. Sehingga apabila terjadi kenaikan DPK sebanyak 1 persen maka akan menyebabkan kenaikan pada penyaluran KPR perbankan syariah sebesar 1,035 persen dengan asumsi variabel lain konstan. Hasil tersebut mengindikasikan bahwa $\mathrm{H}_{3}$ yaitu DPK berpengaruh positif signifikan terhadap KPR diterima, dan hasil ini didukung oleh hasil penelitian Adzimatinur dkk (2017) yang menyatakan bahwa dalam jangka panjang DPK berpengaruh positif terhadap penyaluran pembiayaan perbankan syariah di Indonesia, serta Olokoyo (2011) yang menyatakan bahwa DPK merupakan faktor utama dalam peningkatan penyaluran kredit bank umum di Nigeria.

Selain variabel DPK, terdapat variabel lain yaitu NPF, dimana koefisien regresinya adalah positif tidak signifikan yaitu sebesar 0,043 dengan tingkat probabilitasnya adalah 0,224. Artinya pertumbuhan DPK tidak berpengaruh terhadap penyaluran KPR perbankan syariah. Sehingga apabila terjadi kenaikan NPF sebanyak 1 persen maka tidak akan menyebabkan kenaikan pada penyaluran KPR perbankan syariah sebesar 0,043 persen dengan asumsi variabel lain konstan. Hasil tersebut mengindikasikan bahwa $\mathrm{H}_{4}$ yaitu NPF KPR bepengaruh negatif signifikan terhadap KPR ditolak, dan didukung oleh penelitian Ali dan Miftahurrochman (2015) yang menyatakan bahwa NPF tidak berpengaruh positif terhadap pembiayaan mudharabah perbankan syariah di Indonesia, serta Darmawan (2018) yang menyatakan bahwa NPL tidak berpengaruh positif terhadap penyaluran kredit bank umum di Indonesia.

Sedangkan pada perbankan konvensional adalah sebagai berikut :

$Y_{2}=-1,912+0,103 X 1-0,178 X 2+1,278 X 4$ $+0,014 X_{6}+e$

Berdasarkan persamaan tersebut dapat dijelaskan bahwa nilai koefisien dari variabel suku bunga memiliki nilai koefisien regresi yang positif signifikan yaitu sebesar 0,103 dengan tingkat probabilitas sebesar 0,000 . Artinya pertumbuhan suku bunga berpengaruh terhadap penyaluran KPR perbankan konvensional. Sehingga apabila terjadi kenaikan suku bunga sebanyak 1 persen maka akan menyebabkan kenaikan pada 
Rohman, et al/Jurnal Ekonomi Syariah Teori dan Terapan Vol. 6 No. 10 Oktober 2019: 2077-2094; PENGARUH SUKU BUNGA, NILAI TUKAR, DPK, DAN NPF/NPL KPR TERHADAP PENYALURAN KPR PERBANKAN DI INDONESIA

penyaluran KPR perbankan konvensional sebesar 0,103 persen dengan asumsi variabel lain konstan. Hasil ini mengindikasikan bahwa $H_{1}$ yaitu suku bunga berpengaruh negatif signifikan terhadap KPR ditolak, dan didukung oleh penelitian Darmawan (2017) yang menyatakan bahwa perbankan belum sepenuhnya beracuhan pada Bl Rate dalam menentukan suku bunganya, serta Ibrahim (2006) yang manyatakan bahwa suku bunga berpengaruh positif terhadap penyaluran kredit di negara Malaysia.

Kemudian pada variabel nilai tukar nilai koefisien regresinya adalah negatif signifikan yaitu sebesar - 0,178 dengan tingkat probabilitas sebesar 0,012. Artinya pertumbuhan nilai tukar berpengaruh terhadap penyaluran KPR perbankan konvensional. Sehingga apabila terjadi kenaikan nilai tukar sebanyak 1 persen maka akan menyebabkan penurunan pada penyaluran KPR perbankan konvensional sebesar 0,178 persen dengan asumsi variabel lain konstan. Hasil ini mengindikasikan bahwa $\mathrm{H}_{2}$ yaitu nilai tukar beperengaruh negatif signifikan terhadap KPR diterima dan didukung oleh penelitian oleh Ditria dkk (2008) yang menyatakan bahwa nilai tukar berpengaruh berlawanan terhadap tingkat kredit perbankan, serta Magud dkk (2014) yang menyatakan bahwa semakin tinggi depresiasi nilai tukar domestik maka akan dapat mengurangi kredit suatu perbankan.
Pada Variabel internal perbankan yakni DPK menunjukan nilai koefisien regresi yang positif yaitu sebesar 1,278 dengan tingkat probabilitas sebesar 0,000. Artinya pertumbuhan DPK akan berpengaruh terhadap penyaluran KPR perbankan konvensional. Sehingga apabila terjadi kenaikan DPK sebanyak 1 persen maka akan menyebabkan kenaikan pada penyaluran KPR perbankan konvensional sebesar 1,278 persen dengan asumsi variabel lain konstan. Hasil ini mengindikasikan bahwa $\mathrm{H}_{3}$ yaitu DPK berpengaruh positif signifikan terhadap KPR diterima, dan didukung oleh penelitian Sari (2013) yang menyatakan bahwa DPK berpengaruh positif terhdap penyaluran kredit bank umum di Indonesia, serta Olokoyo (2011) yang menyatakan bahwa DPK merupakan faktor utama dalam peningkatan penyaluran kredit bank umum di Nigeria.

Selain variabel DPK, terdapat variabel lain yaitu NPF, dimana koefisien regresinya adalah positif tidak signifikan yaitu sebesar 0,014 dengan tingkat probabilitas sebesar 0,583. Artinya pertumbuhan NPL KPR tidak akan berpengaruh pada penyaluran KPR perbankan konvensional. Sehingga apabila terjadi kenaikan NPL sebanyak 1 persen maka tidak akan menyebabkan kenaikan pada penyaluran KPR perbankan konvensional sebesar 0,014 persen dengan asumsi variabel lain konstan. Hasil ini mengindikasikan bahwa $\mathrm{H}_{4}$ yaitu NPL berpengaruh negatif 
Rohman, et al/Jurnal Ekonomi Syariah Teori dan Terapan Vol. 6 No. 10 Oktober 2019: 2077-2094; PENGARUH SUKU BUNGA, NILAI TUKAR, DPK, DAN NPF/NPL KPR TERHADAP PENYALURAN KPR PERBANKAN DI INDONESIA

signifikan terhadap KPR ditolak dan didukung oleh penelitian Haryanto dan Widyarti (2017) yang menyatakan bahwa perbankan akan tetap meningkatkan kreditnya apabila NPLnya masih dalam batas aman, serta Mokodompit (2018) yang menyatakan bahwa NPL berpengaruh positif tidak signifikan terhadap penyaluran kredit pada bank umum di Sulawesi Utara.

Sedangkan pada uji simultan dengan uji analisis regresi berganda adalah sebagai berikut:

Tabel 8.

Uji Simultan Perbankan Syariah

\begin{tabular}{|l|r|c|c|}
\hline Model & df & F & Sig. \\
\hline Regression & 4 & 744.649 & $.000^{\mathrm{b}}$ \\
Residual & 50 & & \\
Total & 54 & & \\
\hline
\end{tabular}

Tabel 9.

Uji Simultan Perbankan Konvensional

\begin{tabular}{|l|r|c|c|}
\hline Model & \multicolumn{1}{|c|}{ df } & F & Sig. \\
\hline Regression & 4 & 244.314 & $.000 \mathrm{~b}$ \\
Residual & 49 & & \\
Total & 53 & & \\
\hline
\end{tabular}

Berdasarkan tabel 8 dan 9, diperoleh $F$ hitung perbankan syariah pada penelitian ini adalah sebesar 744,649 dengan nilai signifikannya 0.000 . Sehingga dapat dinyatakan H5 diterima bahwa variabel suku bunga, nilai tukar, DPK, NPF secara simultan berpengaruh signifikan positif terhadap Penyaluran KPR perbankan syariah.

Sedangkan pada perbankan konvensional diketahui bahwa $\mathrm{F}$ hitungnya adalah sebesar 244,314 dengan nilai signifikansi 0,000. Sehingga dapat dinyatakan H5 diterima bahwa variabel suku bunga, nilai tukar, DPK, NPF secara simultan berpengaruh signifikan positif terhadap Penyaluran KPR perbankan konvensional.

\section{Uji Koefisien Determinasi}

Analisis uji koefisien determinasi digunakan untuk mengukur seberapa jauh kemampuan model dalam menerangkan variabel dependen. Adapun hasil uji koefisien determinasi adalah sebagai berikut :

Tabel 10.

Uji Koefisien Determinasi Perbankan Syariah

\begin{tabular}{|l|r|r|}
\hline$R$ & $R$ Square & $\begin{array}{c}\text { Adjusted } R \\
\text { Square }\end{array}$ \\
\hline $.992^{a}$ & .983 & .982 \\
\hline
\end{tabular}

Tabel 11.

Uji Koefisien Determinasi Perbankan Konvensional

\begin{tabular}{|r|r|r|}
\hline$R$ & $R$ Square & $\begin{array}{c}\text { Adjusted } R \\
\text { Square }\end{array}$ \\
\hline $.976 a$ & .952 & .948 \\
\hline
\end{tabular}

Berdasarkan tabel 4.6, dapat diketahui bahwa nilai Adjusted $R^{2}$ adalah 0,982 untuk perbankan syariah dan 0,948 untuk perbankan konvensional. Hal ini menunjukkan bahwa sebesar $\mathbf{9 7 . 9 \%}$ penyaluran KPR perbankan syariah dan 94,8\% penyluran KPR perbankan konvensional dipengaruhi oleh variasi dari keempat variabel independen yang digunakan, yaitu suku bunga, nilai tukar, DPK, dan NPF/NPL sedangkan sisanya 
Rohman, et al/Jurnal Ekonomi Syariah Teori dan Terapan Vol. 6 No. 10 Oktober 2019: 2077-2094; PENGARUH SUKU BUNGA, NILAI TUKAR, DPK, DAN NPF/NPL KPR TERHADAP PENYALURAN KPR PERBANKAN DI INDONESIA

dipengaruhi oleh sebab-sebab lain di luar model penelitian ini.

\section{SIMPULAN}

Berdasarkan penelitian yang telah dilakukan dapat diketahui bahwa suku bunga mempunyai pengaruh positif signifikan pada KPR perbankan syarlah dan perbankan konvensional dikarenakan perbankan masih belum beracuan terhadap suku bunga acuan dalam menentukan tingkat suku bunga ataupun tingkat bagi hasil, hal ini berarti suku bunga acuan tidak dapat mempengaruhi perbankan dalam waktu dekat. Hal tersebut dibuktikan oleh suku bunga ratarata kredit dan tingkat margin rata-rata KPR yang menurun sedikit demi sedikit menjadi 9\% pada Mei 2019 yang sebelumnya adalah 9,56\% pada Mei 2018. Kemudian Nilai tukar berpengaruh positif terhadap penyaluran KPR perbankan syariah dan berpengaruh negatif terhadap penyaluran KPR perbankan konvensional. Pada perbankan syariah, hal tersebut disebabkan tidak adanya penyaluran pembiayaan dalam valas pada sektor KPR dan beralihnya nasabah bank konvensional ke bank syariah saat terjadinya depresiasi kurs rupiah. Sedangkan pada perbankan konvensional, hal tersebut disebabkan adanya penyaluran KPR dalam bentuk valas yang menyebabkan debitur menjadi kesulitan dalam membayar cicilan KPR.
Sedangkan pada variabel internal perbankan yaitu DPK berpengaruh positif terhadap penyaluran KPR perbankan syariah dan perbankan konvensional dikarenakan Semakin tinggi DPK yang dapat dihimpun oleh perbankan, maka semakin tinggi pula KPR yang dapat disalurkan. Selain DPK terdapat Variabel internal lain yaitu NPF/NPL yang berpengaruh positif tidak signifikan yang disebabkan NPF/NPL kedua perbankan cenderung stabil kisaran $2 \%$ - 3\% dimana rasio kecukupan modal masih dapat menampung kerugian yang dimunculkan akibat NPF/NPL KPR. Sehingga perbankan akan terus meningkatkan penyaluran KPRnya walaupun NPF/NPL menunjukan kenaikan.

Kemudian, suku bunga, nilai tukar, DPK dan NPF/NPL KPR secara bersama sama berpengaruh signifikan terhadap penyaluran KPR baik pada perbankan syariah maupun pada perbankan konvensional.

Diharapkan perbankan syariah dapat memanfaatkan secara maksimal dana yang dapat dihimpun dari masyarakat dan memanfaatkan pengukuran kemampuan manajemen bank dalam memperoleh keuntungan sehingga dapat mengimbangi pertumbuhan aktiva produktif. Selain itu, diharapkan untuk penelitian selanjutnya dapat ditambahkan variabel kualitas manajemen umum sehingga kemungkinan memberikan kesimpulan hasil lebih komprehensif. Selain itu, rentang 
Rohman, et al/Jurnal Ekonomi Syariah Teori dan Terapan Vol. 6 No. 10 Oktober 2019: 2077-2094; PENGARUH SUKU BUNGA, NILAI TUKAR, DPK, DAN NPF/NPL KPR TERHADAP PENYALURAN KPR PERBANKAN DI INDONESIA

waktu penelitian juga dapat diperpanjang mengingat laporan KPR untuk perbankan sudah dipisahkan antara perbankan syariah dan perbankan konvensional sejak Oktober 2014.

\section{DAFTAR PUSTAKA}

Adzimatinur, F., Hartoyo, S., \& Wiliasih, R. (2014). Faktor-faktor yang mempengaruhi besaran pembiayaan perbankan syariah di Indonesia. Al-Muzara'ah.

Ali, H., \& Miftahurrohman. (2015). Analisis Pengaruh Dana Pihak Ketiga (Dpk), Non Performing Financing Dan Tingkat Suku Bunga Krdit Terhadap Pembiayaan Berbasis Bagi Hasil (Mudharabah) Pada Perbankan Syariah Indonesia. The Journal Of Tauhidinomics, 1 (2), 151-166.

Bakti, N. S. (2017). Analisis Dpk, Car, Roa Dan Npf Terhadap Pembiayaan Pada Perbankan Syariah. Jurnal Bisnis \& Manajemen, 17(2), 15-28.

Damayanti, N. P. (2014). Pengaruh Financing To Deposit Ratio (Fdr), Non Performing Financing (Npf) Dan Return On Equity (Roe)Terhadap Pembiayaan Murabahah Pada Bank Syariah Di Indonesia. Sekolah Tinggi IImu Ekonomi Perbanas Surabaya.

Darmawan, A. (2017). Faktor-Faktor Yang Mempengaruhi Kebijakan Penyaluran Kredit Perbankan Pada Bank Umum Di Indonesia Tahun 2010-2015. Universitas Negeri Yogyakarta.
Darmawan, A. (2018). Influence of Loan Interest Rate, Non-Performing Loan, Third Party Fund and Inflation Rate towards Micro, Small and Medium Enterprises (MSME) Credit Lending Distribution at Commercial Banks in Indonesia. In 2018 3rd International Conference on Education, Sports, Arts and Management Engineering (ICESAME 2018) (pp. 308-311). Atlantis Press.

Dendawijaya, L. (2005). Manajemen Perbankan (Kedua, p. 82). Jakarta: Ghalia Indonesia.

Fikri, A. (1357). al-Mu'amalat al-Madiyah al-Adabiyyah. Cairo: Mustafa alBab al-Halabi.

Fitzpatrick, T., \& McQuinn, K. (2007). House Prices and Mortgage Credit: Empirical Evidence For Ireland. The Manchester School, 75(1), 82-103.

Ghozali, I. (2011). Aplikasi Analisis Multivariate Dengan Program SPSS. Semarang: Badan Penerbit Universitas Diponegoro.

Gujarati, N. . (2003). Basic Econometrics. Fourth Edition. New York: McGrawHill/Irwin.

Hardjono. (2008). Mudah Memiliki Rumah Lewat KPR. Jakarta: PT. Pustaka Grahatama.

Haryanto, S. B., \& Widyarti, E. T. (2017). ANALISIS PENGARUH NIM, NPL, BOPO, BI RATE DAN CAR TERHADAP PENYALURAN KREDIT BANK UMUM PERIODE TAHUN 2012-2016. 
Rohman, et al/Jurnal Ekonomi Syariah Teori dan Terapan Vol. 6 No. 10 Oktober 2019: 2077-2094; PENGARUH SUKU BUNGA, NILAI TUKAR, DPK, DAN NPF/NPL KPR TERHADAP PENYALURAN KPR PERBANKAN DI INDONESIA

DIPONEGORO JOURNAL OF MANAGEMENT, 6(4), 1-11.

Hasibuan. (2009). Dasar-dasar Perbankan. Jakarta: PT. Bumi Aksara.

Ibrahim, M. H. (2006). Stock Prices and Bank Loan Dynamics in a Developing Country: The Case of Malaysia. Journal of Applied Finance Economics, 9(1), 71-89.

Kasmir. (2012). Dasar-dasar Perbankan: Edisi Revisi. Jakarta: PT. Grafindo Persada.

Kuncoro, Mudrajad, \& Suhardjono. (2011). Manajemen Perbankan. Yogyakarta: BPFE.

Magud, N., CM, R., \& ER, V. (2014). Capital inflows, exchange rate flexibility and credit booms. Review of Development Economics, 18(3), 415-430.

Mokodompit, F. (2018). ANALISIS FAKTORFAKTOR YANG MEMPENGARUHI PENYALURAN KREDIT PADA BANK UMUM DI SULAWESI UTARA (PERIODE 2010.1-2015.4). Jurnal Berkala Ilmiah Efisiensi, 18(3), 47-57.

Nofita, N. L. I., Ayuningsasi, A. A. K., \& Swara, I. W. Y. (2018). PENGARUH DPK, NPL, LDR DAN BI RATE TERHADAP JUMLAH KREDIT YANG DISALURKAN OLEH BPR DI PROVINSI BALI. E-Jurnal EP Unud, 7(8), 16151643.

Nugraheni, P. P., \& Meiranto, W. (2013). PENGARUH FAKTOR INTERNAL BANK DAN SERTIFIKAT BANK INDONESIA TERHADAP PENYALURAN KREDIT
PERBANKAN DI INDONESIA. DIPONEGORO JOURNAL OF ACCOUNTING, 2(4), 1-11.

Nurrochman, I. (2016). ANALISIS FAKTORFAKTOR YANG MEMENGARUHI PEMBIAYAAN PADA BANK UMUM SYARIAH (STUDI PADA BANK UMUM SYARIAH TAHUN 2012-2015). DIPONEGORO JOURNAL OF MANAGEMENT, 5(3), 1-14.

Oktaviani. (2012). Pengaruh DPK, ROA, CAR, NPL, Dan Jumlah SBI Terhadap Penyaluran Kredit Perbankan (Studi Pada Bank Umum Go Public Di Indonesia Periode 2008-2011). Universitas Diponegoro.

Olokoyo, F. O. (2011). Determinants of commercial banks lending behavior in Nigeria. International Journal of Financial Research, 2(2), 61-72.

Pratiwi, R. D. (2014). Faktor-Faktor yang Mempengaruhi Tingkat Pengguliran Dana Bank Umum Non Devisa Syariah Tahun 2010-2012. Media Ekonomi \& Teknologi Informasi, 22(1), 15-31.

Putra, I. G. O. P., \& Rustariyuni, S. D. (2015). PENGARUH DPK, BI RATE, DAN NPL TERHADAP PENYALURAN KREDIT MODAL KERJA PADA BPR DI PROVINSI BALI TAHUN 2009-2014. EJurnal EP Unud, 4 (5), 451-464.

Rinaldy, E. (2008). Membaca Neraca Bank (Pertama, p. 30). Jakarta: Karya Gemilang. 
Rohman, et al/Jurnal Ekonomi Syariah Teori dan Terapan Vol. 6 No. 10 Oktober 2019: 2077-2094; PENGARUH SUKU BUNGA, NILAI TUKAR, DPK, DAN NPF/NPL KPR TERHADAP PENYALURAN KPR PERBANKAN DI INDONESIA

Sabar, W., \& Kuslin. (2018). MENAKAR DAMPAK SUKU BUNGA, NILAI TUKAR, DAN INFLASI TERHADAP PERMINTAAN KREDIT KONSUMSI. AlMashrafiyah: Jurnal Ekonomi, Keuangan, Dan Perbankan Syariah, 2(2), 77-91.

Sari, G. N. (2013). Faktor-Faktor Yang Mempengaruhi Penyaluran Kredit Bank Umum Di Indonesia (Periode 2008.1 - 2012.2). Jurnal Riset Ekonomi, Manajemen, Bisnis Dan Akuntansi, 1 (3), 931-941.

Siamat, D. (2005). Management Lembaga Keuangan: Kebijakan Moneter dan Perbankan. Jakarta: Lembaga Penerbit UI.

Suprihatin. (2017). PENGARUH KURS, INFLASI, DANA PIHAK KETIGA (DPK), DAN PENDAPATAN BANK TERHADAP PEMBIAYAAN PADA BANK UMUM SYARIAH DEVISA
PERIODE 2014-2016. IAIN SURAKARTA.

Tandris, R. (2014). Suku Bunga, Inflasi, dan Nilai Tukar Pengaruhnya Terhadap Permintaan Kredit Pada Perbankan di Kota Manado. Jurnal EMBA: Jurnal Riset Ekonomi, Manajemen, Bisnis, Dan Akuntansi., 2(1), 243253.

Undang - Undang No.10 Tahun 1998 tentang perbankan. (1998). Kementrian Keuangan RI.

Yusof, R. M., Usman, F. H., Mahfudz, A. A., \& Arif, A. S. (2018). Macroeconomic Shocks, Fragility And Home financing In Malaysia: Can Rental Index Be The Answer? Journal of Islamic Accounting and Business Research, 9(1), 17-44. https://doi.org/10.1 108/JIABR-1 12015-0058 